\title{
Modes of transmission of Loma salmonae (Microsporidia)
}

\author{
R. W. Shaw ${ }^{1,2, *}$ M. L. Kent ${ }^{2}$, M. L. Adamson ${ }^{1}$ \\ ${ }^{1}$ Department of Zoology, 6270 University Boulevard, University of British Columbia, Vancouver, British Columbia V6T 1Z4, Canada \\ ${ }^{2}$ Department of Fisheries and Oceans, Pacific Biological Station, Nanaimo, British Columbia V9R 5K6, Canada
}

\begin{abstract}
Loma salmonae (Putz, Hoffman and Dunbar, 1965) Morrison and Sprague, 1981 (Microsporidia) causes prominent gill disease in pen-reared chinook salmon Oncorhynchus tshawytscha in the Pacific Northwest. Transmission of the parasite was examined by exposing Pacific salmon Oncorhynchus spp. to infectious spores by various routes: per os, intraperitoneal, intramuscular, and intravascular injection, by cohabitation with infected fish, and by placement of spores directly on the gill. All exposure methods led to infections except placement of spores on the gill. Putative sporoplasms were visible in epithelial cells of the alimentary canal within $24 \mathrm{~h}$ of per os exposure. L. salmonae may initialiy infect alimentary epithelial cells and then migrate into the lamina propria to access the blood stream. Positive results obtained by intravascular injection suggest that autoinfection from spores of ruptured xenomas in the endothelium may also occur. The cohabitation exporiment demonstrates that fish may become infected by spores released from live fish.
\end{abstract}

KEY WORDS: Loma salmonae Microspondia Transmission

\section{INTRODUCTION}

Loma salmonae (Putz, Hoffman and Dunbar, 1965) Morrison and Sprague, 1981 is a microsporidian parasite infecting endothelial cells of salmonids. Fish infected with $L$. salmonae often exhibit pale gills with petechial hemorrhages, inflammation, hyperplasia, and white cysts termed xenomas (Wales \& Wolf 1955. Hauck 1984, Kent 1992), Outbreaks of L. salmonae in Pacific salmon Oncorhynchus spp. and rainbow trout O. mykiss have occurred in the Pacific Northwest (Hauck 1984, Kent et al. 1989), eastern United States (Markey et al. 1994), and Scotland (Bruno et al. 1995).

Kent et al. (1995) demonstrated that fish can be infected by Loma salmonae when ingesting infected tissues. Whereas details on the early development of Loma species are unknown, for microsporidia in general the spore extrudes a polar filament which pierces a gut epithelial cell and injects the parasite's sporoplasm. For genera such as Loma and Glugea, the

•E-mail: rwshaw@unixg.ubc.ca sporoplasm eventually divides, forming numerous spores within a hypertrophied cell (i.e. a xenoma) (Canning \& Lom 1986).

Loma salmonae has been transmitted experimentally both in fresh and sea water by feeding fish macerated gills containing spores (Kent et al. 1995). Hauck (1984) suggested that gills may be infected directly by phagocytic uptake of pillar cells. However, the method by which Loma spp. spread within the host is unknown. It may be spread by infected macrophages, or by utilising body fluids (Hauck 1984). In the present study, experimental transmission of $L$. salmonae to chinook Oncorhynchus tshawytscha and coho O. kisutch was attempted by various routes: per os, intraperitoneal (IP), intramuscular (IM), and intravascular (IV) injection, cohabitation of infected fish with naive fish, and placement of $L$. salmonae spores directly on the gills.

\section{MATERIALS AND METHODS}

Fish husbandry. Fish were obtained from Rosewall Creek Hatchery, Fisheries and Oceans Canada, Van- 
couver Island, Canada. This hatchery receives only well water and has no history of the disease. Unless noted elsewhere, all fish were held in flow-through tanks receiving 14 to $16^{\circ} \mathrm{C}$ dechlorinated tresh water. Before handling, fish were anesthetised with tricaine methanesulfonate (MS-222). During sampling fish were killed with an overdose of MS-222; the first left gill arch of each fish was examined by wet mount for Loma salmonae. The rest of the gills were placed in Davidson's solution (Humason 1979) along with the heart, stomach, intestine, kidney, liver, and spleen, and a section of dorsal muscle for histology. All these tissues were processed using standard histological techniques. Experiments were terminated at 56 d, unless otherwise noted, to allow sufficient time for development of visible xenomas (Kent et al 1995)

Preparation of parasite. Spores of Loma salmonae were purified from infected chinook gills obtained from a seawater netpen site on the west coast of Vancouver Island. Gill tissue suspended in dechlorinated fresh water was ground using a Polytron tissue homogeniser (Luzer, Switzerland) to create a slurry. This slurry was centrifuged at $2000 \times g$ for $10 \mathrm{~min}$. The pellet was resuspended in water and filtered through a wire mesh and then through a $50 \mu \mathrm{m}$ nylon screen. The filtrate was then centrifuged at $800 \times g$ for 45 min on a layered $34 \% / 51 \%$ Percal gradient. Pure spores were collected from the pellet and the $34 \% / 51 \%$ layer.

Exposure protocol. Loma salmonae spores were introduced directly into the stomach using a $16 \mathrm{~g}$ needle tipped with $2.0 \mathrm{~mm}$ inner diameter tubing as either a gill tissue slurry $(0.25 \mathrm{ml})$ or as a suspension of pure spores $(0.1 \mathrm{ml})$. For anal gavage, a $22 \mathrm{~g}$ needle tipped with $0.58 \mathrm{~mm}$ inner diameter tubing was used. Various amounts of pure spores (Tables $1 \& 2$ ) in $0.1 \mathrm{ml}$ innocula were used for anal gavage, IP, IM, and IV injections. IV injections were given using the ventral gill sinus or dorsal aorta.

Various trials were conducted using the above exposure methods as outlined in Tables $1 \& 2$. Controls had their left ventral fin clipped and were kept in the same tank as exposed fish. In trial 6, controls were injected with Earle's Buffered Saline Solution (EBSS) and blood smears were collected at all sampling times from fish receiving IV injections. For trial 3 , blood smears from 3 fish were made within 30 min of injection. Smears were air dried, heat and methanol fixed, and an indirect fluorescent antibody test (IFAT) was conducted to locate spores. Monoclonal antibody (MAB) for Loma salmonae developed using standard techniques (Schots et al. 1992) was provided by F. Markham, Department of Pathology and Microbiology, Atlantic Veterinary School, Charlottetown, Prince Edward Island, Canada. The MAB (225 $\mu$ l) was applied directly to blood smears and allowed to incubate at room temperature for
30 min. The smears were washed 3 times and incubated in phosphate buffered saline (PBS) at pH 7.2 for $10 \mathrm{~min}$. Fluorescein isothiocynate (FITC) conjugated goat anti-mouse IgG antibody diluted in PBS (1:128) was counterstained with 1\% Evan's blue (1:156) and applied to the smears. Smears were incubated for $30 \mathrm{~min}$, washed 3 times and incubated for $10 \mathrm{~min}$ in PBS. IFAT slides were examined with a fluorescent microscope at $\times 1000$ using $\mathrm{pH} 9$ mounting fluid (Difco).

In trial 4, pure spores $(0.1 \mathrm{ml}$ ) were placed directly on the left gill arch of 10 chinook held out of water for $1 \mathrm{~min}$. After $1 \mathrm{~min}$, each chinook was dipped for $5 \mathrm{~s}$ in a rimse bucket before being placed in the holding tank. Controls were passed through the rinse bucket before

Table 1 Loma salmonae in Oncorhynchus tshawytscha and $O$. kisutch. Infection of $L$. salmonae in chinook and coho salmon exposed by various routes. Fish were examined at $56 \mathrm{~d}$ post-exposure and considered positive upon detection of the parasite in wet mounts or histological sections

\begin{tabular}{|c|c|c|}
\hline Trial & $\begin{array}{l}\text { No. of fish } \\
\text { exposed }\end{array}$ & $\begin{array}{l}\text { No. positive/ } \\
\text { No. examined }\end{array}$ \\
\hline \multicolumn{3}{|c|}{ Trial 1} \\
\hline \multirow{2}{*}{\multicolumn{3}{|c|}{$\begin{array}{l}\text { Chinook (avg. } 16.6 \mathrm{~cm} ; 38.4 \mathrm{~g} \text { ) } \\
\text { Spore dosage (except controls) }=2.8 \times 10^{\circ}\end{array}$}} \\
\hline & & \\
\hline Peros & 10 & $9 / 10$ \\
\hline Anal gavage & 10 & $10 / 10$ \\
\hline Control & 4 & $0 / 4$ \\
\hline \multicolumn{3}{|l|}{ Trial 2} \\
\hline \multirow{2}{*}{\multicolumn{3}{|c|}{$\begin{array}{l}\text { Coho (avg. } 18.8 \mathrm{~cm} ; 60.1 \mathrm{~g} \text { ) } \\
\text { Spore dosage }=1.2 \times 10^{6}\end{array}$}} \\
\hline & & \\
\hline Peros & 10 & $9 / 9$ \\
\hline Intraperitonea] & 10 & $8 / 8$ \\
\hline Intravasculard & 10 & $10 / 10$ \\
\hline \multicolumn{3}{|l|}{ Trial 3} \\
\hline \multicolumn{3}{|c|}{ Chinook (avg. $23.2 \mathrm{~cm} ; 119.2 \mathrm{~g}$ ) } \\
\hline \multicolumn{3}{|c|}{ Spore dosage (except controls) $=5.9 \times 10^{5}$} \\
\hline Per os & 4 & $4 / 4$ \\
\hline Intravascular b.c & 13 & $10 / 10$ \\
\hline Control & 4 & $0 / 4$ \\
\hline \multicolumn{3}{|l|}{ Trial 4} \\
\hline \multicolumn{3}{|c|}{ Chinook (avg. $11.2 \mathrm{~cm}_{i} 12.9 \mathrm{~g}$ ) } \\
\hline \multicolumn{3}{|c|}{ Spore dosage (except controls) $=2.8 \times 10^{\mathrm{h}}$} \\
\hline Gill arch & 10 & $0 / 10$ \\
\hline Control & 2 & $0 / 2$ \\
\hline \multicolumn{3}{|l|}{ Trial 5} \\
\hline \multicolumn{3}{|l|}{ Cohabitation exposure } \\
\hline \multicolumn{3}{|c|}{ Donor chinook (avg. $19.8 \mathrm{~cm} ; 66.4 \mathrm{~g}$ ) } \\
\hline \multicolumn{3}{|c|}{ Recipient chinook (avg. $12.4 \mathrm{~cm} ; 17.4 \mathrm{~g}$ ) } \\
\hline Donor fish (spore dosage $=1.25$ & $\left.0^{5}\right) 10$ & $10 / 10$ \\
\hline Recipient fish, 24 h exposure ${ }^{d}$ & 45 & $3 / 10$ \\
\hline Recipient fish, 3 d exposure ${ }^{d}$ & 35 & $7 / 10$ \\
\hline Recipient fish, $5 \mathrm{~d}$ exposure ${ }^{\mathrm{d}}$ & 25 & $6 / 10$ \\
\hline Recipient fish, $7 \mathrm{~d}$ exposure ${ }^{\mathrm{d}}$ & 15 & $10 / 10$ \\
\hline \multirow{2}{*}{\multicolumn{3}{|c|}{$\begin{array}{l}\text { "Injection by ventral gill sinus } \\
\text { bInjection by dorsal aorta }\end{array}$}} \\
\hline & & \\
\hline \multicolumn{3}{|c|}{$\begin{array}{l}\text { 'Spores detected in blood by an indirect fluorescent anti- } \\
\text { body test (IFAT) }\end{array}$} \\
\hline \multicolumn{3}{|c|}{$\begin{array}{l}\text { dFish removed at time indicated and raised separately for } \\
56 \mathrm{~d} \text { before examination }\end{array}$} \\
\hline
\end{tabular}

Trial 1

Chinook (avg. $16.6 \mathrm{~cm} ; 38.4 \mathrm{~g}$ )

Trial 2

Coho (ave. $18.8 \mathrm{~cm}, 60.1 \mathrm{~g}$ )

Intravascular ${ }^{\circ}$$$
\begin{gathered}
8 / 8 \\
10 / 10
\end{gathered}
$$

Spore dosage (except controls) $=5.9 \times 1.0$

Per os

$10 / 10$

Trial 4

Gill arch

Contro

$0 / 10$

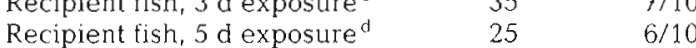

Recipient fish, 7 d exposure

bInjection by dorsal aorta

Spores detected in blood by an indirect fluorescent antibody test (IFA'T)

$56 \mathrm{~d}$ before examination 
being placed in the same tank. The same innoculum was used here as in trial 1.

For trial 5, donor chinook were infected per os and held for $72 \mathrm{~d}$ at 12 to $14^{\circ} \mathrm{C}$. Ten donor fish with clinical signs of Loma salmonae (anemia and petechial hemorrhages on gills) were placed in a 204 l tank with 45 naive chinook (differentiated by size from infected fish). After exposure periods, sets of 10 recipient fish were removed (Table 1). Following $7 \mathrm{~d}$ cohabitation (i.e. $79 \mathrm{~d}$ post-exposure of donor fish), all donor fish were examined for $L$. salmonae. Intensity of infection in donors was measured from the average of 3 counts of the number of xenomas per $\times 100$ field of view (1.5 mm diameter).

\section{RESULTS}

All exposure methods, except placement of Loma salmonae spores directly on the gill, resulted in infection (Tables 1 \& 2). When administered per os, spores were found within $6.5 \mathrm{~h}$ in histological sections of stomach in free material and in association with epithelial cells (Figs. 1 \& 2). Between 2.5 and 24 h possible sporoplasms were found in epithelial cells of the stomach and pyloric caeca. These stages contained darkstaining, probably nuclear, material and a lighter-staining outer area. At $24 \mathrm{~h}$ epithelial cells of the anterior intestine contained these sporoplasms, and some sporoplasms were also associated with the lamina propria (Figs. 3-5). These structures were not found in controls or in fish sampled at 35 or $56 \mathrm{~d}$.

Loma salmonae spores were detected in the blood by IFAT after fish received IV injections via the dorsal aorta and up to $24 \mathrm{~h}$ after injections via the ventral gill

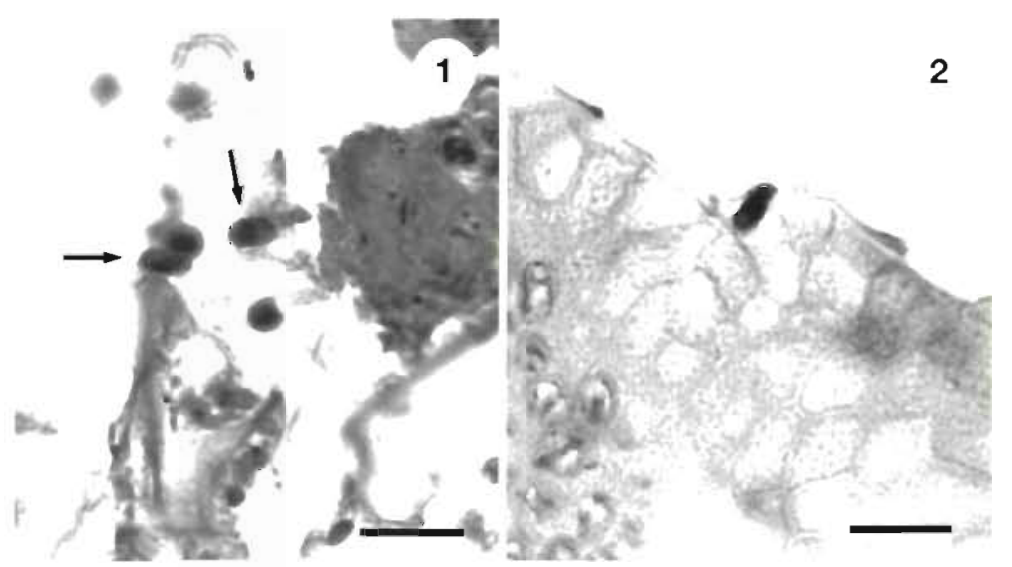

Figs. 1 \& 2. Loma salmonae in Oncorhynchus kisutch. Hematoxylin \& eosin sections of $L$. salmonae spores in coho salmon infected per os and sampled within 6.5 h. Fig. 1. Spores in stomach material denoted by arrows. Scale bar $=12 \mu \mathrm{m}$. Fig. 2 . Single spore in association with stomach epithelial cells. Scale bar $=12 \mu \mathrm{m}$
Table 2. Loma salmonae in Oncorhynchus kisutch. Infection of $L$. salmonae in coho salmon from trial 6 exposed by various routes to $1.2 \times 10^{\text {h }}$ spores per fish (except controls). Fish were considered positive upon detection of the parasite in wet mounts or histological sections

\begin{tabular}{|c|c|c|c|}
\hline $\begin{array}{l}\text { Mode of } \\
\text { exposure }\end{array}$ & $\begin{array}{l}\text { No. of } \\
\text { fish }\end{array}$ & $\begin{array}{l}\text { Time } \\
\text { examined }\end{array}$ & $\begin{array}{l}\text { No positive/ } \\
\text { No. examined }\end{array}$ \\
\hline Control & 16 & $\begin{array}{c}2.5 \mathrm{~h}^{\mathrm{d}} \\
6.5 \mathrm{~h}^{\mathrm{d} . \mathrm{b}} \\
24 \mathrm{~h}^{\mathrm{d}} \\
35 \mathrm{~d} \\
56 \mathrm{~d} \\
2.5 \mathrm{~h}-56 \mathrm{~d}\end{array}$ & $\begin{array}{l}0 / 2 \\
0 / 2 \\
0 / 2 \\
1 / 2 \\
7 / 8 \\
0 / 8\end{array}$ \\
\hline Intraperitoneal & 16 & $\begin{array}{c}2.5 \mathrm{~h} \\
6.5 \mathrm{~h} \\
24 \mathrm{~h} \\
35 \mathrm{~d} \\
56 \mathrm{~d} \\
2.5 \mathrm{~h}-56 \mathrm{~d}\end{array}$ & $\begin{array}{l}0 / 2 \\
0 / 2 \\
0 / 2 \\
0 / 2 \\
3 / 4 \\
0 / 4\end{array}$ \\
\hline Intravascular ${ }^{c}$ & 16 & $\begin{array}{c}2.5 \mathrm{~h}^{\mathrm{d}} \\
6.5 \mathrm{~h}^{\mathrm{d}} \\
24 \mathrm{~h}^{\mathrm{d}} \\
35 \mathrm{~d} \\
56 \mathrm{~d} \\
2.5 \mathrm{~h}-56 \mathrm{~d}\end{array}$ & $\begin{array}{l}0 / 2 \\
0 / 2 \\
0 / 2 \\
1 / 2 \\
6 / 6 \\
0 / 8\end{array}$ \\
\hline Intramuscular & 16 & $\begin{array}{c}2.5 \mathrm{~h} \\
6.5 \mathrm{~h} \\
24 \mathrm{~h} \\
35 \mathrm{~d} \\
56 \mathrm{~d} \\
2.5 \mathrm{~h}-56 \mathrm{~d}\end{array}$ & $\begin{array}{l}0 / 2 \\
0 / 2 \\
0 / 2 \\
1 / 2 \\
6 / 7 \\
0 / 7\end{array}$ \\
\hline \multicolumn{4}{|c|}{$\begin{array}{l}\text { "Possible sporoplasms detected in alimentary canal } \\
\text { b Spores detected in histological sections of stomach } \\
\text { "Injection by ventral gill sinus } \\
\text { "Spores detected in blood by IFAT }\end{array}$} \\
\hline
\end{tabular}

sinus (Fig. 6). By 56 d all fish given IP injections had swollen kidneys and spleens, petechial hemorrhaging, and bloody ascites. This was not seen in fish infected per os or in controls. One fish given an IV injection showed edema and hemorrhaging. Fish receiving IM injections of spores exhibited edema and a pronounced inflammatory response in muscle tissue at the site of injection by $35 \mathrm{~d}$ (infection shown after $56 \mathrm{~d}$ in Fig. 7). No inflammatory changes were seen in controls. In trial 6 (Table 2) xenomas were first detected $35 \mathrm{~d}$ post-infection in the gills, heart and spleen. Xenomas were found most often in the gills followed by heart and spleen (Table 3). Xenomas were not found in intestine, liver, muscle, or stomach.

Xenomas in donor fish (Table 1; trial 5) were completely opaque and filled with spores. Intensity in donor fish was 2.32 xenomas (range 1 to 6.3 ) per $\times 100$ field of view. 


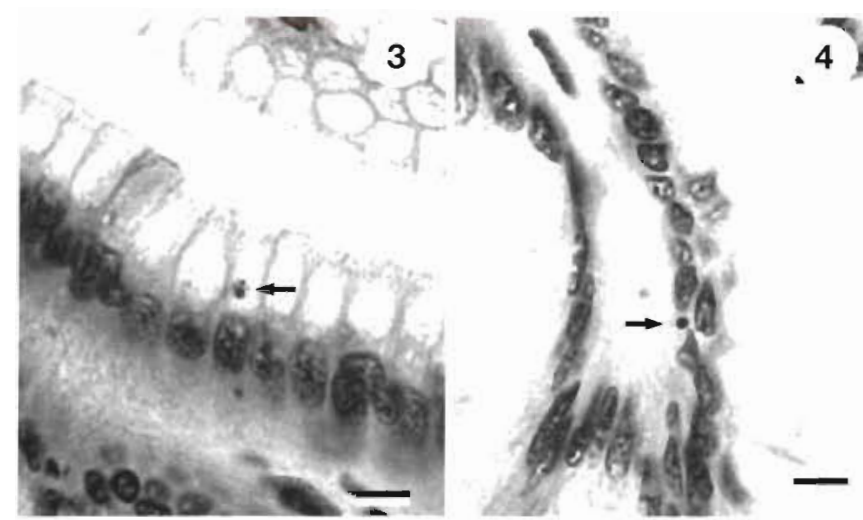

\section{DISCUSSION}

Oncorhynchus spp. were susceptible to Loma salmonae administered by per os, anal gavage, IP, IM, and IV injection, and by cohabitation with infected fish. Microsporidia such as Glugea, Heterosporis, Microsporidium, and PJeistophora that infect fish species have been successfully experimentally transmitted by per os, IP, and IM injection, and by water-borne exposure (Lom 1969, Awakura 1974, McVicar 1975, Leiro et al. 1994). Water-borne infections can result from direct immersion in a spore solution (Awakura 1974, T'sui et al. 1988), or by feeding a crustacean, previously exposed to spores, to fish (Awakura 1974, Olson 1976 , 1981). L. salmonae has been transmitted per os to chinook (Kent \& Dawe 1994) and rainbow trout O. mykiss (Speare et al, 1998a). In addition Speare et al. (1998b) transmitted $L$. salmonae per os and by IP injection of

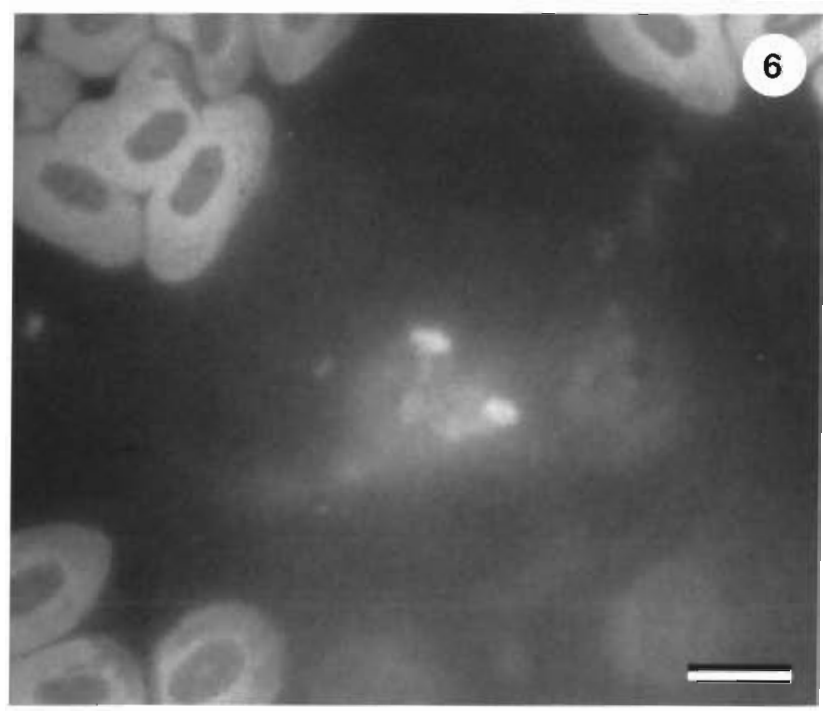

Fig. 6. Loma salmonae in Oncorhynchus kisutch. L. salmonae spores detected by IFAT in the blood of coho salmon within $24 \mathrm{~h}$ of fish being injected with pure spores via the ventral gill sinus. Scale bar $=12 \mu \mathrm{m}$

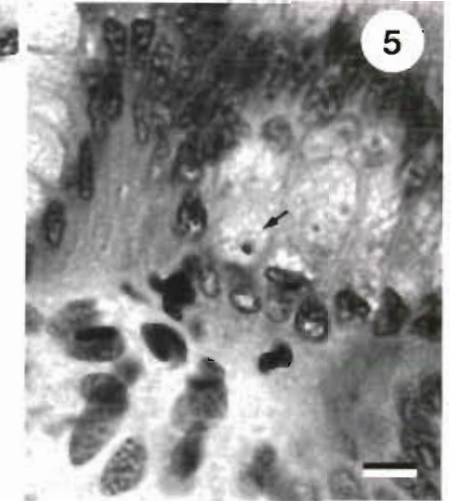

Figs 3 to 5. Loma salmonae in Oncorhynchus kisutch. Hematoxylin \& eosin sections of possible sporoplasms (denoted by arrows) of $L$. salmonae in anterior intestinal epithelial cells of coho salmon infected per os and sampled within $24 \mathrm{~h}$ Fig. 3. Sporoplasm in intestinal cell. Scale bar $=$ $6 \mu \mathrm{m}$. Figs. 4 \& 5. Sporoplasms in association with lamina propria of intestinal cells. Scale bar $=6 \mu \mathrm{m}$ semi-purified spores to rainbow trout. Hauck (1984) suggested phagocytic uptake of Loma sp. by gill pillar cells as water passes through the gills. Our findings do not support this hypothesis as spores placed directly on gills did not result in infection.

Association of Loma salmonae spores with stomach epithelial cells, and possible sporoplasms released from spores located within epithelial cells of the stomach, pyloric caeca, and anterior intestine, most likely indicate initial sites of infection. Spores discharging polar filaments may pierce gut epithelial cells, injecting infective sporoplasms. These could migrate and enter the lamina propria, which is richly supplied with blood capillaries. It is generally believed that microsporidia that infect fish enter gut epithelial cells, where they develop or are then transported to their preferred site of development (Canning \& Lom 1986). These microsporidia might infect migratory cells such as histio-

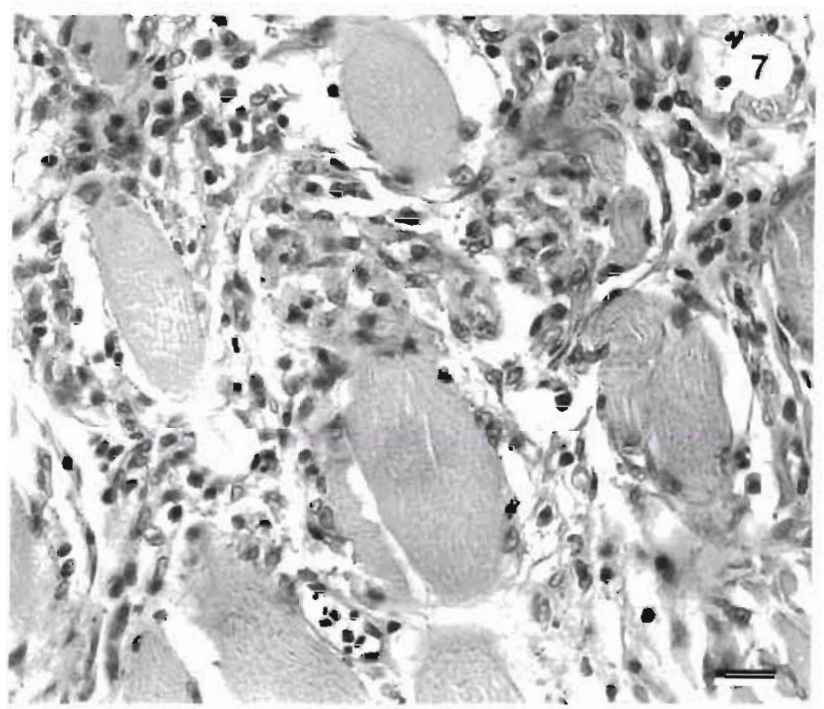

Fig. 7. Loma salmonae in Oncorhynchus kisutch. Pronounced inflammatory response in coho salmon muscle after $56 \mathrm{~d}$ in association with intramuscular injection of $L$. salmonae spores Hematoxylin \& easin. Scale bar $=6 \mu \mathrm{m}$ 
Table 3. Loma salmonae in Oncorhynchus kisutch. Distribution of $L$. salmonae in organs of coho salmon from trials 2 and 6 combined, at $56 \mathrm{~d}$ after exposure by various routes. Values for tissue are percentage of fish showing infection in organ indicated

\begin{tabular}{|lrrrrr|}
\hline Infection method & $\begin{array}{c}\text { No. of } \\
\text { fish }\end{array}$ & Gill & \multicolumn{4}{c|}{ Tissue } \\
& & & & \\
& 17 & 100.0 & 22.2 & 17.6 & 0.0 \\
Peros & 12 & 92.2 & 41.7 & 41.7 & 25.0 \\
Intraperitoneal & 16 & 100.0 & 43.8 & 41.2 & 6.3 \\
Intravascular & 7 & 85.7 & 14.3 & 0.0 & 0.0 \\
Intramuscular & & & & & \\
\hline
\end{tabular}

cytes, neutrophils or macrophages (Weissenberg 1968, McVicar 1975, Canning \& Lom 1986). Matthews \& Matthews (1980) proposed that macrophages act as a transport mechanism for Tetramicra brevifilum Matthews \& Matthews, 1980 through the endothelium of turbot Scophthalmus maximus, or become infected themselves during phagocytosis of the parasite in the lamina propria of the intestine. However, to our knowledge none of these hypotheses have been previously experimentally demonstrated. Further studies using in situ hybridisation will probably elucidate the site of initial infection and how subsequent spread of $L$. salmonae occurs within the fish host. Docker et al. (1997) developed a polymerase chain reaction (PCR) test for L. salmonae which would be useful for this purpose.

Autoinfection within fish-infecting microsporidia has also been proposed but not verified (Lom \& Dyková 1992). The systemic distribution of Loma sp. xenomas and free spores suggests that, as xenomas rupture, infective stages are liberated and move throughout the fish via the blood (Hauck 1984, Markey et al. 1994). Our experiments, in which free spores injected into the blood resulted in xenoma formation in the gills support the hypothesis that autoinfection of L. salmonae may occur, i.e. in natural infections, xenomas may rupture in blood vessels and free spores may circulate and establish new xenomas. The high concentration of xenomas in the gills compared to other organs, regardless of the route of exposure, suggests that the gill endothelium is the preferred site of development of $L$. salmonae, rather than a coincidental site of infection due to route of exposure or circulatory patterns.

Transmission of Loma salmonae from infected to naive fish within $24 \mathrm{~h}$ of cohabitation in a flow-through system indicates how readily the parasite may be transmitted. Kano et al. (1982) noted that Heterosporis anguillarum Hoshina, 1951 (syn. Pleistophora anguillarum) spread to healthy eels from infected eels in the same aquarium. During cohabitation in our study, naive fish may have ingested spores from ruptured or whole xenomas released from the gills (i.e. the secondary lamellae) of infected fish. Spores could also be liberated in fish urine when fish have kidney infections (Hauck 1984).

Our results demonstrate that Loma salmonae is transmissible by experimental (e.g IP, IM.) and natural (e.g. per os, cohabitation) exposure routes. Infection by IV injection and distribution of xenomas throughout vascular tissue suggest that once a fish is infected, $L$. salmonae may spread within the host by autoinfection. Kent et al. (1995) proposed that $L$. salmonae spreads within a seawater netpen site via spores released from decomposing fish or by other fish feeding on the remains of mortalities. Salmonid farmers should be aware of this and the possibility of live infected fish transmitting the parasite to naive fish when formulating management strategies to control the infection.

Acknowledgements. Funding for this research was provided by NSERC strategic grant no. 582073. We thank the fish farm companies involved in this project, S. St-Hilaire for help with injecting fish, S. Dawe for assistance with initial photographics preparations, and F. Markham for providing the Loma-specific monoclonal antibody.

\section{LITERATURE CITED}

Awakura T (1974) Studies on the microsporidian infection in salmonid fishes. Sci Rep Hokkaido Fish Hatchery 29:1-96

Bruno DW, Collins RO, Morrison CM (1995) The occurrence of Loma salmonae (Protozoa: Microspora) in farmed rainbow trout, Oncorhynchus mykiss Walbaum, in Scotland. Aquaculture 133:341-344

Canning EU, Lom J (1986) The Microsporidia of vertebrates. Academic Press, New York, p 1-39

Docker MF, Devlin RH, Richard J, Khattra J, Kent ML (1997) Sensitive and specific polymerase chain reaction assay for detection of Loma salmonae (Microsporea). Dis Aquat Org 29:41-48

Hauck AK (1984) A mortality and associated tissue reactions of chinook salmon, Oncorhynchus tshawytscha (Walbaum), caused by the microsporidian Loma sp. J Fish Dis $7: 217-229$

Humason GL (1979) Animal tissue techniques, 4th edn. WH Freeman, San Francisco

Kano T, Okauchi T, Fukui H (1.982) Studies on Pleistophora infection in eel. Anguilla japonica-1I. Preliminary tests for application of fumagillin. Fish Pathol 17:107-114

Kent ML (1992) Diseases of seawater netpen-reared salmonid fishes in the Pacific Northwest. Can Spec Publ Fish Aquat Sci 116:39-42

Kent ML, Dawe SC (1994) Efficacy of Fumagillin DCH against experimentally induced Loma salmonae (Microsporea) infections in chinook salmon Oncorhynchus tshawytscha. Dis Aquat Org 20:231-233

Kent ML, Dawe SC. Speare DJ (1995) Transmission of Loma salmonae (Microsporea) to chinook salmon in sea water Can Vet J 36:98-101

Kent ML, Elliott DG, Groff JM, Hedrick RP (1989) Loma salmonae (Protozoa: Microspora) infections in seawater reared coho salmon Oncorhynchus kisutch. Aquaculture 80:211-222

Leiro J, Estévez J, Ubeira FM, Santamarina MT, Sanmartin ML (1994) Seriological relationships between two microsporidian parasites of fish. Aquaculture 125:1-9 
Lom J (1969) Experimental transmission of a microsporidian Plistophora hyphessobryconis, by intramuscular transplantation. I Protozool 16:17

Lom J, Dyková I (1992) Developments in aquaculture and fisheries science, Vol 26. Protozoan parasites of fishes. Elsevier Science, Amsterdam, p 125-157

Markey PT, Blazer VS, Ewing MS, Kocan KM (1994) Loma $\mathrm{sp}$, in salmonids from the Eastern United States: associated lesions in rainbow trout. J Aquat Anim Health 6: 318-328

Matthews RA, Matthews BF (1980) Cell and tissue reactions of turbot Scophthalmus maximus (L.) to Tetramicra brevifilum gen. N., sp. n. (Microspora). J Fish Dis 3:495-515

McVicar AH (1975) Infection of plaice Pleuronectes platessa L. with Glugea (Nosema) stephani (Hagenmüller 1899) (Protozoa: Microsporidia) in a fish farm and under experimental conditions. J Fish Biol 7:611-619

Olson RE (1976) Laboratory and field studies on Glugea stephani (Hagenmïller), a mirrnsnoridan parasite of pleuronectid flatfishes. J Protozool 23:158-164

Olson RE (1981) The effect of low temperature on the development of a microsporidan Glugea stephani in English sole (Parophrya vetulus). J Wildl Dis 17:559-562

Editorial responsibility: Wolfgang Korting

Hannover, Germany
Schots A, Pomp R, Muiswinkel WB (1992) Production of monoclonal antibodies. In: Stolen JA, Fletcher TC, Anderson DP, Kaattari SL, Rowley AF (eds) Techniques in fish immunology, Vol 2. SOS Publications, Fair Haven, NJ, p $1-18$

Speare DJ, Arsenault GJ, Boute MA (1998a) Evaluation of rainbow trout as a model species for studying the pathogenesis of the branchial microsporidian Loma salmonae. Contemp Top Lab Anim Sci 37:55-58

Speare DJ, Beaman HJ, Jones SRM, Markham RJF, Arsenault GJ (1998b) Induced resistance of rainbow trout to gill disease associated with the microsporidian gill parasite Loma salmonae. J Fish Dis 21:93-100

T'sui WN, Wang CH, Lo CF (1988) On the Plistophora infection in eel II. The development of Plistophora anguillarum in experimentally infected elvers, Anguilla japonica. Bull Inst Zool Acad Sin 27:249-258

Wales $\mathrm{JH}$, Wolf $\mathrm{H}$ (1955) Three protozoan diseases of trout in California. Calif Fish Game 41:183-187

Weissenberg R (1968) Intracellular development of the microsporidian Glugea anomala Moniez in hypertophying migra. tory cells of the fish Gasterosteus aculeatus L., an example of the formation of 'xenoma tumors'. J Protozool 15:44-57

Submitted: December 15, 1997; Accepted: March 10, 1998 Proofs received from author(s): May 25, 1998 